\title{
Pledge, Promise, or Commit: New York's Tenuous Limitations on Judicial Campaign Speech
}

Noah Hertz-Bunzl

Follow this and additional works at: https://digitalcommons.tourolaw.edu/lawreview

Part of the Constitutional Law Commons, First Amendment Commons, and the Judges Commons

\section{Recommended Citation}

Hertz-Bunzl, Noah (2013) "Pledge, Promise, or Commit: New York's Tenuous Limitations on Judicial Campaign Speech," Touro Law Review. Vol. 29: No. 3, Article 6.

Available at: https://digitalcommons.tourolaw.edu/lawreview/vol29/iss3/6

This Article is brought to you for free and open access by Digital Commons @ Touro Law Center. It has been accepted for inclusion in Touro Law Review by an authorized editor of Digital Commons @ Touro Law Center. For more information, please contact Iross@tourolaw.edu. 
Pledge, Promise, or Commit: New York's Tenuous Limitations on Judicial Campaign Speech

Cover Page Footnote

29-3

This article is available in Touro Law Review: https://digitalcommons.tourolaw.edu/lawreview/vol29/iss3/6 


\title{
Pledge, Promise, or Commit: NeW York's Tenuous Limitations ON JUdicial CAMPaign SPEeCH
}

\author{
Noah Hertz-Bunzl*
}

A decade has passed since Republican Party of Minnesota $v$. White, ${ }^{1}$ the landmark Supreme Court decision loosening speech restrictions on judicial candidates. ${ }^{2}$ White involved the announcements of legal and political views. ${ }^{3}$ New York limits speech concerning the extent to which judicial candidates may pledge, promise, or commit to legal or political positions. ${ }^{4}$ As these categories partially overlap in their applicability to a given campaign statement, New York judicial candidates must carefully navigate what they can and cannot say to avoid disciplinary censure. ${ }^{5}$ This Article sets out to determine the precise delineation of what can and cannot be said in New York and whether the legal speech that remains is a constitutionality valid limit. Ultimately, the restrictions are problematic because of the limited state interest in restricting judicial candidate $\operatorname{speech}^{6}$ and the false idea that speech that does not favor one set of legal interests or class of litigants over another can be sufficiently meaningful to the electorate to satisfy the relevant First Amendment interests. ${ }^{7}$

White concerned First Amendment limitations on Minnesota's ability to prohibit judicial candidates "from announcing their views

\footnotetext{
* Law Clerk, United States District Court for the Southern District of Florida, 2013-2014. Associate, Carter Ledyard \& Milburn, 2012-2013. J.D., Fordham University School of Law, 2012; B.A., Harvard College, 2008. I am grateful to Professor Zephyr Teachout for her guidance in the development of this article.

1536 U.S. 765 (2002).

2 Id. at 768,788 .

3 Id. at 768.

4 Matter of Shanley, 774 N.E.2d 735, 736 (N.Y. 2002) (per curiam).

5 Id.

6 Walter M. Weber, Judicial Campaign Speech Restrictions: Some Litigation Nuts and Bolts, 68 ALB. L. REV. 635, 642 (2005).

7 Nat Stern, The Looming Collapse of Restrictions on Judicial Campaign Speech, 38 SETON Hall L. REV. 63, 64 (2008).
} 
on disputed legal and political issues." ${ }^{8}$ This prohibition in Minnesota's Code of Judicial Conduct, known as the "announce clause," had been based on the 1972 American Bar Association ("ABA") Model Code of Judicial Conduct. ${ }^{9}$ The petitioner, a candidate for the Minnesota Supreme Court, had distributed literature criticizing the court's decisions. ${ }^{10}$ Following a disciplinary inquiry, the petitioner filed suit seeking a declaration that the clause was unconstitutional because it forced him to refrain from announcing views on disputed issues. ${ }^{11}$ The lower federal courts rejected these claims. ${ }^{12}$

Justice Scalia, writing for the Court, identified that "the announce clause prohibits a judicial candidate from stating his views on any specific nonfanciful legal question within the province of the court for which he is running, except in the context of discussing past decisions," as long as the candidate does not oppose stare decisis. ${ }^{13}$ Respondents pointed out that the clause left room for discussions about candidate character, education, and work habits, as well as specific positions on issues such as cameras in the courtroom. ${ }^{14}$

The Court applied strict scrutiny because the clause "prohibits speech on the basis of its content and burdens" the speech of candidates for public office, which is a core First Amendment freedom. ${ }^{15}$ Scalia evaluated the state interests of impartiality and the appearance of impartiality, finding that the clause was not narrowly tailored because while impartiality is a concern based on parties, the announce clause restricts speech not for or against parties, but for or against issues. ${ }^{16}$ The clause also does not serve the interest of judicial openmindedness because sitting judges may state their views in classes,

${ }^{8}$ White, 536 U.S. at 768.

9 Id. The ABA canon was changed in 1990 due to First Amendment concerns. Id. at 773 n.5. It was replaced with a canon prohibiting judicial candidates from making "statements that commit or appear to commit the candidate with respect to cases, controversies or issues that are likely to come before the court." Id. (quoting Model CODE OF Judicial CONDUCT Canon 5(A)(3)(d)(ii) (2000)) (internal quotation marks omitted).

${ }^{10} I d$. at 768. The literature criticized a decision to exclude confessions from "criminal defendants that were not tape-recorded" as an indication that the court did not trust the police. White, 536 U.S. at 771. The literature also "criticized a decision requiring public financing of abortions for poor women as 'unprecedented' and a 'pro-abortion stance.' " Id.

11 Id. at 769-70.

$12 I d$. at 770.

13 Id. at 773 .

14 White, 536 U.S. at 774.

15 Id. To survive strict scrutiny the clause must be "(1) narrowly tailored, to serve (2) a compelling state interest." Id. at 774-75.

16 Id. at 775-76. 
books, and speeches, and candidate positions make up a small proportion of the positions sitting judges will take over the course of their careers. ${ }^{17}$

Scalia identified the tension between the election of judges and the announce clause "which places most subjects of interest to the voters off limits." 18 This is not surprising because the ABA, the original proponent of the clause, has long been a supporter of judicial merit selection and an opponent of elections. ${ }^{19}$ While opposition to elections may be well grounded, the First Amendment does not allow this goal to be achieved by leaving elections in place but "preventing candidates from discussing what the elections are about." ${ }^{20}$

Scalia distinguished the announce clause from the clause in the state code prohibiting candidates "from making "pledges or promises of conduct in office other than the faithful and impartial performance of the duties of the office, ' - a prohibition that is not challenged here and on which we express no view." 21 Thus, announcing views "on an issue covers much more than promising to decide an issue a particular way." 22

Justices Ginsburg, Stevens, Souter and Breyer dissented. ${ }^{23}$ Ginsburg identified distinctions between judges and other elected officials that should lead to different First Amendment treatment. ${ }^{24}$ Unlike other elected officials, "[j]udges . . . are not political actors," and "they serve no faction or constituency." 25

Ginsburg emphasized the importance of Minnesota's pledges or promises clause. ${ }^{26}$ The "judicial obligation to avoid prejudgment corresponds to the litigant's [due process] right ... to 'an impartial and disinterested tribunal.' "27 When candidates make promises about issues that may reach the courts, if they are elected they "will be under pressure to resist the pleas of litigants who advance posi-

7 Id. at $778-79$.

18 White, 536 U.S. at 787.

19 Id.

20 Id. at 787-88.

21 Id. at 770 (citation omitted) (quoting MinN. CodE OF Judicial ConduCt Canon $5(\mathrm{~A})(3)(\mathrm{d})(\mathrm{i})(2002))$.

${ }^{22}$ Id.

23 White, 536 U.S. at 803 (Ginsburg, J., dissenting).

24 Id. at 803-05.

25 Id. at 806.

26 Id. at 812-13.

27 Id. at 813 (quoting Marshall v. Jerrico, Inc., 446 U.S. 238, 242 (1980)). 
tions contrary to her pledges on the campaign trail."28 However, " $[\mathrm{u}]$ ncoupled from the Announce Clause, the ban on pledges or promises is easily circumvented. By prefacing a campaign commitment with the caveat, 'although I cannot promise anything,' . . . a candidate could declare with impunity how she would decide specific issues." 29 The announce clause is therefore an indispensable part of the pledge or promises clause and "constitutional for the same reasons." $" 30$

White had a nationwide impact on state judicial conduct codes. $^{31}$ New York has a pledge or promise clause, but not an announce clause. ${ }^{32}$ In the aftermath of White, the New York Court of Appeals decided Matter of Shanley. ${ }^{33}$ The petitioner sought review of a decision of the New York State Commission on Judicial Conduct ("Commission") concerning "campaign literature in which she [had] identified herself as a 'Law and order Candidate." ",34

"In the Commission's view, the phrase created the appearance that petitioner would favor the prosecution, and amounted to an impermissible pledge as to how she would decide cases." 35 According to widely held perceptions, "the phrase promises stern treatment of criminal defendants." "36 The Court of Appeals disagreed with the result, finding that the phrase did not compromise judicial impartiali-

28 White, 536 U.S. at 816 (Ginsburg, J., dissenting).

29 Id. at 819.

30 Id. at 820-21.

31 See Stern, supra note 7 (stating that many states revised their judicial codes of conduct following White).

32 See infra note 35.

33774 N.E.2d 735 (N.Y. 2002) (decided July 1, 2002). White was decided on June 27, 2002. 536 U.S. 765.

34 Shanley, 774 N.E.2d at 736 . Commission decisions are appealed directly to the Court of Appeals. N.Y. Judiciary LAw § 44(7) (McKinney 2012).

35 Shanley, 774 N.E.2d at 736 . The actions at issue would violate the state's Rules Governing Judicial Conduct prohibiting judicial candidates from making "pledges or promises of conduct in office" that are inconsistent with the "impartial performance of the [adjudicative] duties of the office" and "with respect to cases, controversies or issues that are likely to come before the court," make commitments that are inconsistent with the "impartial performance of the [adjudicative] duties of the office." See id. (referencing N.Y. ComP. CoDES, R. \& REgs. tit. 22, § 100.5(A)(4)(d)(i-ii)). The ABA Model Code of Judicial Conduct provides that "a judge or a judicial candidate shall not . . . in connection with cases, controversies, or issues that are likely to come before the court, make pledges, promises, or commitments that are inconsistent with the impartial performance of the adjudicative duties of judicial office." Model Code of Judicial Conduct R. 4.1(A)(13) (2010).

36 Shanley, 774 N.E.2d at 737. 
ty. ${ }^{37}$ " 'Law and order' is a phrase widely and indiscriminately used in everyday parlance and election campaigns. We decline to treat it as a 'commit[ment]' or a 'pledge[] or promise[] of conduct in office." " 38

The next year the Court of Appeals decided Matter of Watson. ${ }^{39}$ In the course of his campaign for judicial office, William Watson sent a letter to law enforcement personnel asking them to "put a real prosecutor on the bench." ${ }^{40}$ Watson indicated in a newspaper advertisement that "he had "proven experience in the war against crime. " "41 Watson also made a statement to a reporter indicating that he would reduce court caseloads by cracking down on crime, causing criminals to go elsewhere. ${ }^{42}$

The Court of Appeals identified tension with White, finding the pledges or promises clause at issue in the case "sufficiently circumscribed" to withstand First Amendment scrutiny. ${ }^{43}$ The clause is limited because it "precludes only those statements of intention that single out a party or class of litigants for special treatment" or convey a candidate will behave inconsistently with their judicial duties, leaving permissible "most statements identifying a point of view." 44

$[S]$ tatements that merely express a viewpoint do not amount to promises of future conduct. On the other hand, candidates need not preface campaign statements with the phrase "I promise" before their remarks may reasonably be interpreted by the public as a pledge to act or rule in a particular way if elected. A candidate's statements must be reviewed in their totality and in the context of the campaign as a whole to determine whether the candidate has unequivocally articulated a pledge or promise of future conduct .... ${ }^{45}$

Here, Watson violated this rule by expressing a bias in favor of the

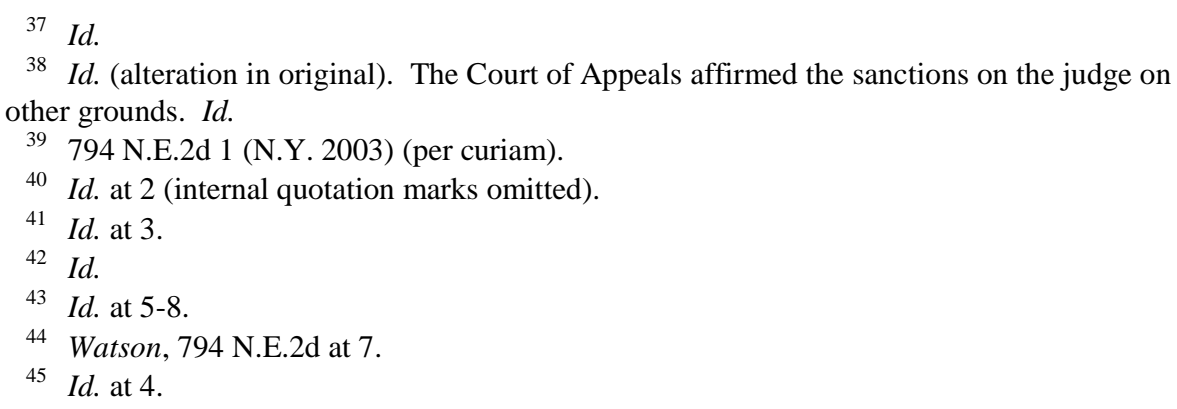


police and implying he would use his powers to keep certain kinds of defendants out of the city, and did so repeatedly throughout the campaign. ${ }^{46}$

In 2009, the Commission considered charges against Margaret Chan stemming from her election campaign for New York City Civil Court. ${ }^{47}$ Chan had released literature advertising a planned lecture that stated, "Margaret Chan and Veteran Tenant Attorney Steven DeCastro will show you how to stick up for your rights, beat your landlord, . . . and win in court!"48

The Commission identified violations of the pledges, promises, and commitments clauses. ${ }^{49}$

[Chan's] literature may have given prospective voters the impression that she would favor tenants over landlords in housing matters, which are often the subject of Civil Court proceedings. By distributing such literature, which appeared to commit herself with respect to issues likely to come before her court, she compromised her impartiality. ${ }^{50}$

Commission member Richard D. Emery dissented. ${ }^{51}$ Emery pointed out that the literature only "may have led a prospective voter to conclude that [Judge Chan] would favor tenants," which is not enough to show a promise, pledge, or commitment. ${ }^{52}$ "[A]n election campaign by necessity must be designed to appeal to voters based on the candidate's history and activities." 53 "If certain constituents feel they can predict a judicial candidate's views on controversial subjects that $\mathrm{s} / \mathrm{he}$ may have to someday face in court, that is part of the price

46 Id. The court upheld the ruling of the Commission, but modified the sanction from removal to censure. $I d$. at 8.

47 Matter of Chan, 2010 N.Y. ANN. REP. 124-26, available at http://www.cjc.ny.gov/Publications/ AnnualReports/nyscjc.2010annualreport.pdf\#page= [hereinafter Chan].

48 Id. at 126 (alterations in original). The Commission also considered other violations relating to the personal solicitation of campaign contributions and a misrepresentation of an endorsement. $I d$. at $124-26$.

49 Id. at 127.

50 Id. Based on this and other violations, the Commission admonished Chan. Chan, supra note 47 , at 128 .

51 Id. at 129 (Emery, Comm'r, dissenting). The Commission has eleven members and each serves a renewable four-year term. See Commission Members, N.Y. Commission on JUD. CONDUCT, http://www.scjc.state.ny.us/General.Information/Gen.Info.Pages/members.htm (last updated Apr. 2, 2013).

52 Chan, supra note 47, at 129 (Emery, Comm'r, dissenting).

53 Id. 
we pay for the free flow of information critical to the electoral choice of judges." $" 54$

Emery recognized that the Court of Appeals in Watson held that implied promises of future conduct may be the basis for discipline, a decision "in tension with White." 55 But, while Watson involved implicit promises and commitments, Chan's criticism of landlords does not rise to an implied promise because a voter only may have come to the conclusion that she was pledging to rule a certain way. ${ }^{56}$ By finding misconduct for statements that urge "voters to know their rights against landlords," which is not an actual pledge, promise, or commitment, "the Commission is adding a gloss on White that cannot be justified by any reading of that decision." 57

In 2010, the Commission considered written complaints against Rensselaer County Supreme Court Justice Patrick J. McGrath for a letter he sent during his campaign to pistol permit holders. ${ }^{58}$ The text of the letter stated the following:

As your County Judge for the past 14 years, I have been responsible for all pistol permits in Rensselaer County. My pistol permit is very important to me as I know yours is to you .... ...

As Supreme Court Justice . . . I will still be responsible for all pistol permits in Rensselaer County. ${ }^{59}$

The Commission found that the statements conveyed bias to favor pistol permit holders and their interests, reinforcing an implied promise that he would look after their interests and thus violated the rule against improper pledges, promises, and commitments. ${ }^{60}$ "Campaign statements that single out a particular class of litigants for special treatment are inconsistent with judicial impartiality and the appear-

54 Id. at 130.

55 Id. at 131.

$56 I d$. at 132. Emery noted that New York's rules were changed in 2006 to remove the prohibition on statements that " 'appear to commit' the candidate with respect to controversies and issues ... limiting misconduct to an express commitment." Chan, supra note 47, at 132.

57 Id. at 131.

58 Matter of McGrath, 2011 N.Y. ANN. REP. 120-21, available at http://www.cjc.ny.gov/Publications/AnnualReports/nyscjc.2011 annualreport.pdf\#page= [hereinafter McGrath].

$59 I d$. at 121 (third alteration in original).

60 Id. at $122-23$. 
ance of impartiality . ..."

The Commission made a number of decisions on similar issues prior to White. ${ }^{62}$ In the following three instances, the Commission found a violation of the "pledges and promises" and "commit or appear to commit" clauses. ${ }^{63}$ Matter of Birnbaum involved a brochure that "asserted that voters had a 'clear choice' between respondent . . . a tenant, and his opponent . . . a landlord."64 The "literature gave the unmistakable impression that he would favor tenants over landlords in housing matters." 65

Matter of Hafner, Jr. involved literature "that stated: 'Are you tired of seeing career criminals get a 'slap' on the wrist? So am I'" and the phrase, referring to an opponent, that "[s]oft judges make hard criminals!"66 The literature implied respondent "would deal harshly with all such defendants, rather than judge the merits of individual cases."67 Matter of La Cava involved a letter sent to Right-toLife Party members in which the candidate "asserted his "commitment to the sanctity of life from the moment of conception' " and an interview with a reporter in which the candidate stated that abortion is murder. ${ }^{68}$ This statement "created the appearance" that La Cava "might not follow constitutional and statutory law if called upon to do so." $" 69$

The New York State Advisory Committee on Judicial Ethics ("Ethics Committee") is an independent body that responds to written ethics inquiries from state judges. ${ }^{70}$ The Ethics Committee has de-

61 Id. at 123.

62 See infra note 64.

63 See Matter of Hafner, Jr., 2001 N.Y. ANN. REP. 113-14 (2001), available at http://www.cjc.ny.gov/Publications/AnnualReports/nyscjc.2001annualreport.pdf\#page= [hereinafter Hafner, Jr.]; Matter of La Cava, 2000 N.Y. ANN. REP. 124 (2000), available at http://www.cjc.ny.gov/Publications/AnnualReports/nyscjc.2000annualreport.pdf\#page= [hereinafter La Cava]; Matter of Birnbaum, 1998 N.Y. ANN. ReP. 74 (1998), available at http://www.cjc.ny.gov/Publications/AnnualReports/nyscjc.1998annualreport.pdf\#page= [hereinafter Birnbaum]. The "appear to commit" language was removed in 2006. See supra note 56.

64 Birnbaum, supra note 63, at 73. The brochure included quotations favorable to respondent from tenants who appeared before him in housing court, including tenants in cases then pending before respondent. Id.

65 Id. at 74.

66 Hafner, Jr., supra note 63, at 113 (first alteration in original).

67 Id. at 114.

68 LaCava, supra note 63, at 123.

69 Id. at 124.

70 About the ACJE: Organization and Purpose, N.Y. ST. Advisory COMM. ON Jud. 
termined that a candidate should not respond to a questionnaire from a pro-Second Amendment organization because the form "contains requests for positions on issues which may regularly come before the inquiring judge should the judge" be elected. ${ }^{71}$ The Ethics Committee has held that a candidate may not distribute campaign statements that indicate an opposition to engaging in plea-bargaining in criminal cases as it would constitute an impermissible pledge or promise. ${ }^{72}$ The Ethics Committee did find that it would be permissible to include in campaign literature a photograph taken with a relative, a state trooper in uniform, as long as the context did not suggest the candidate would favor law enforcement interests. ${ }^{73}$

Judicial candidates are given advice about how to campaign within the boundaries of the law. The New York State Bar Association has placed on its website a guide for judicial candidates that includes a section on avoiding campaign "[p]itfalls."74

[A] public pronouncement of these views [on disputed legal or political issues] may be seen as an indication of how the candidate would decide cases as a judge and would give the impression that the candidate would not approach a case involving those issues with an open mind. Accordingly, the candidate should not announce his or her views on disputed legal or political issues if it is foreseeable that such issues may bear upon a case that may come before the court in the future. $^{75}$

The advice to judicial candidates is that to be on the safe side, a candidate should say less rather than more about their views.

ETHICS, available at http://www.nycourts.gov/ip/acje/whatis.shtml (last visited May 10, 2013).

71 N.Y. Advisory Comm. on Judicial Ethics Op. 99-33 (1999), available at http://www.nycourts.gov/ip/judicialethics/opinions/99-33_htm. The rules applied were the pledge or promise clause and the commit or appear to commit clause. Id.

72 N.Y. Advisory Comm. on Judicial Ethics Op. 04-95 (2004), available at http://www.nycourts.gov/ip/judicialethics/opinions/04-95_.htm.

${ }^{73}$ N.Y. Advisory Comm. on Judicial Ethics Op. 07-136 (2007), available at http://www.nycourts.gov/ip/judicialethics/opinions/07-136.htm.

${ }^{74}$ See The High Road-Rules for Conducting a Judicial Campaign in New York, N.Y. ST. BAR ASS'N SPECIAL COMM. ON JUD. CAMPAIGN CONDUCT, available at http://www.nysba.org/Content/NavigationMenu/ForAttorneys/ProfessionalStandardsforAttor neys/JudicialCampaignGuidelines.pdf (last visited May 10, 2013) [hereinafter The High Road].

75 Id. 
The vast majority of states that have judicial elections have some form of a pledge, promise, or commit clause in their canons of judicial conduct. ${ }^{76}$ The constitutionality of such clauses after White has been the subject of litigation in other states. The Supreme Court of Florida has upheld the clauses. ${ }^{77}$ Other courts have upheld the clauses with narrow constructions. ${ }^{78}$ A number of federal district courts have found the provisions to be unconstitutional, on their face $^{79}$ or as applied. ${ }^{80}$ Some federal appellate courts have rejected challenges to the clauses based on ripeness or standing grounds. ${ }^{81}$ The general consensus among the scholarship is that the promises clauses are on shaky ground after White. ${ }^{82}$

There is a strong free speech interest at play. Judicial elec-

76 See Judicial Campaigns and Elections: Campaign Conduct, AM. JudiCATURE SoC'Y, http://www.judicialselection.us/judicial_selection/campaigns_and_elections/campaign_cond uct.cfm?state $=($ last visited May 10, 2013). Thirty-nine states have some version of a "commit" clause. Carey v. Wolnitzek, 614 F.3d 189, 207-09, 218 (6th Cir. 2010) (remanding to the District Court on the question of the clause's constitutionality).

77 In re Kinsey, 842 So.2d 77, 87 (Fla. 2003) (stating pledge, promise, commit, and appear to commit clauses serve a "compelling state interest in preserving the integrity of our judiciary and maintaining the public's confidence in an impartial judiciary").

78 See Pa. Family Inst., Inc. v. Celluci, 521 F. Supp. 2d 351, 356, 382, 387 (E.D. Pa. 2007) (finding the clauses constitutional, but that the clauses, narrowly construed, allow judicial candidates to answer questionnaires from the Pennsylvania Family Institute and other groups); Kan. Judicial Review v. Stout, 196 P.3d 1162, 1174-75 (Kan. 2008) (stating clauses permit statements of viewpoints, but not pledges, promises or commitments that bind judges to a particular disposition on a certain issue or controversy).

79 See N.D. Family Alliance, Inc. v. Bader, 361 F. Supp. 2d 1021, 1039 (D.N.D. 2005) (pledge, promise, and commitment clauses are too broadly tailored to serve the interests of judicial impartiality toward parties and are protected by White); Family Trust Found. of Ky., Inc. v. Wolnitzek, 345 F. Supp. 2d 672, 697-98, 703 (E.D. Ky. 2004) (the clauses impermissibly burden free speech because "the types of general promises prohibited by the clauses are merely announcements of legal views" which are protected).

${ }^{80}$ Duwe v. Alexander, 490 F. Supp. 2d 968, 976 (W.D. Wis. 2007) (the provisions are not unconstitutional on their face but would be as applied to judicial candidates responding to a survey from Wisconsin Right to Life).

${ }^{81}$ See Alaska Right to Life Political Action Comm. v. Feldman, 504 F.3d 840, 844 (9th Cir. 2007) (vacating on ripeness grounds); Bauer v. Shepard, 620 F.3d 704, 716-18 (7th Cir. 2010) (affirming on ripeness grounds); Pa. Family Inst., Inc. v. Black, 489 F.3d 156, 159 (3d Cir. 2007) (affirming on standing and ripeness grounds).

82 See Michelle T. Friedland, Disqualification or Suppression: Due Process and the Response to Judicial Campaign Speech, 104 ColuM. L. REV. 563, 607-08 (2004); Stern, supra note 7, at 121; Note, The Rule of Law in the Marketplace of Ideas: Pledges or Promises by Candidates for Judicial Election, 122 HARv. L. REv. 1511, 1532 (2009) [hereinafter The Rule of Law]. But see Kathleen M. Sullivan, Republican Party of Minnesota v. White: What are the Alternatives?, 21 Geo. J. Legal Ethics 1327, 1345 (2008); Gerald Stern, A Fine Line: The First Amendment and Judicial Campaigns, 77 N.Y. ST. B.J. 10, $16-17$ (2005). 
tions may be inferior to the appointment of judges. ${ }^{83}$ But if we are to have elections, they should be elections in which voters have meaningful choice. ${ }^{84}$ If voters cannot pick candidates based on issues, other factors will decide judicial elections. ${ }^{85}$ Voters may choose a judge solely based on resume or qualifications, instead of choosing a judge with whom they politically or legally identify. In addition, the lack of information for voters may allow for the increased influences of the legal establishment, party leadership, or pure cronyism.

On the other hand, the state has a strong interest in an impartial judiciary. ${ }^{86}$ This interest may be persuasive in connection to the announce, pledge, promise, or commit clauses. For example, it certainly would be problematic if a sitting judge revealed a position that implicated a case directly before his or her courtroom at that time. ${ }^{87}$ This is less of a concern with non-incumbent judicial candidates.

In the scheme of issues facing states in the administration of judicial elections, however, broad restrictions on judicial speech should be a minor concern. A far more serious concern should be the role of money in judicial elections. ${ }^{88}$ Judicial election spending has more than doubled between 2000 and 2009 compared to the 1990s, and was especially high during the 2010 elections. ${ }^{89}$ A majority of Americans believe that campaign funding buys "favorable legal outcomes." 90 The Supreme Court has recently ruled that due process required a state supreme court judge to recuse himself in a situation in

83 See White, 536 U.S. at 787-88.

84 Id. at 788.

85 See Stephen Gillers, "If Elected I Promise [__ ] "What Should Judicial Candidates Be Allowed to Say?, 35 IND. L. REV. 725, 733 (2002) (“Absent information about a candidate's views on legal questions that may come before his or her court, voters will have to rely solely on information whose relationship to professional merit is often marginal-party affiliation, advertisements that emphasize symbols and dramatic scenes, the ethnic identity of candidates, and endorsements.").

86 White, 536 U.S. at 817 (Ginsburg, J., dissenting).

87 Sitting judges in New York are prohibited from making "any public comment about a pending or impending proceeding in any court." Rules Governing Judicial Conduct, N.Y. Comp. Codes, R. \& Regs. tit. 22, § 100.3(B)(8). Sitting judges are also bound by the pledge, promise, and commit prohibitions. Id. at $\S 100.3(\mathrm{~B})(9)$. See also The Rule of Law, supra note 82 , at 1531 ("[P] rohibiting statements regarding individual cases or litigants would not sweep in constitutionally protected speech ....").

88 Adam Skaggs \& Andrew Silver, Promoting Fair and Impartial Courts Through Recusal Reform, BRENNAN CENTER FOR JUST. (2011), available at http://brennan.3cdn.net/09c926c04c9eed5290

_e4m6iv2v0.pdf.

$89 I d$. at $1-2$.

90 Id. at 1. 
which a contributor gave that judge $\$ 3$ million and the judge ruled significantly in the contributor's favor. ${ }^{91}$ It is true that the promises clauses speak to a related interest of the litigant to air disputes "before judges who have not committed to rule against them before the opening brief is read." ${ }^{92}$

Commission member Richard Emery has expressed similar frustrations about the New York rules. Emery concurred and dissented to the removal of Judge Thomas Spargo, who provided coffee and doughnuts to voters and committed other violations of the rules. ${ }^{93}$ Emery found it "ironic" that the rules punish small giveaways to voters, but allow candidates to receive contributions from party officials, "as well as from the lawyers whose very livelihoods depend on the judges who receive their contributions." 94 The rules "are a patchwork of compromises and ad hoc judgments which fail to address the central causes of the unseemliness of judicial campaigns: party control and the candidate's need to raise money." ${ }^{95}$

Therefore, the rules, according to Emery, are not narrowly tailored because they restrict candidates in the "opposite way one would expect in order to safeguard judicial integrity." ${ }^{, 96}$ Counteracting the role of money in judicial campaigns is a much more urgent state interest than limiting what political positions candidates can take in an election. If there is a compelling state interest in an impartial judiciary, there are rules that the state can implement which would be far more effective toward reaching this goal and far less prohibitive on core speech interests than limiting judicial speech.

A pressing concern for New York judicial candidates might be to determine what exactly is or is not prohibited by state rules and

91 Caperton v. A.T. Massey Coal Co., 556 U.S. 868, 872-74 (2009). New York's recusal rules have recently been strengthened. See William Glaberson, New York Takes Step on Money in Judicial Elections, N.Y. TIMES (Feb. 13, 2011), http://www.nytimes.com/2011/02/ 14/nyregion/14judges.html?_r=0.

92 Carey v. Wolnitzek, 614 F.3d 189, 207 (6th Cir. 2010) (citing Caperton, 556 U.S. at 887).

${ }^{93}$ Matter of Spargo, 2007 N.Y. ANN. REP. 136-37 (2007), available at http://www.scjc.state.ny.us/Publications/AnnualReports/nyscjc.2007annualreport.pdf (Emery supported the determinations on some charges and not others).

94 Id. at 140 .

95 Id. at 141.

96 Matter of Farrell, 2005 N.Y. ANN. REP. 160-61 (2005), 166, available at http://www.cjc.ny.gov/Publications/AnnualReports/nyscjc.2005annualreport.pdf (Emery concurred in finding that the judge violated the rules through improper political party support). 
precedents. Matter of Watson would suggest that the key metric for determining when a judicial statement is an unlawful pledge, promise, or commitment is when a class or party of litigants is singled out for special treatment. ${ }^{97}$ William Watson therefore violated the rules by showing a bias in favor of the police, and Margaret Chan violated the rules by showing a bias in favor of tenants. ${ }^{98}$

Matter of Shanley provides an exception to Watson. ${ }^{99}$ The phrase "[1] aw and order [c]andidate" was permissible because it is a phrase used in everyday parlance. ${ }^{100}$ It is also permissible for a candidate to appear in a photograph taken with a relative, a state trooper in uniform. ${ }^{101}$ Thus, not very well-developed statements by candidates are likely permissible. ${ }^{102}$ While you cannot advertise a lecture with a pro-tenant activist to show attendees how to stick up for their rights, ${ }^{103}$ it is likely permissible to merely state you are a pro-tenant candidate. ${ }^{104}$ While stating your support of "law and order" is permissible, expressing the same sentiment, repeatedly and enthusiastically in different forums, as in Watson, is not. ${ }^{105}$

There may be some logic to this approach. An announcement and a promise could be distinguished by the degree to which you seem willing to follow up on your words, and the demonstration of an attachment to a certain position would be the evidence. But this is an ill-conceived method of making the distinction. The import is that if voters will be unable to get a true picture of your intentions, you can

97 See Watson, 794 N.E.2d at 7. Judicial candidates may also violate these clauses by conveying that their behavior will be inconsistent with their judicial duties. Id. By making pro-life statements, the Commission found that Justice La Cava conveyed he might not follow constitutional and statutory precedent. La Cava, supra note 63, at 124 . This is similar but distinct from the idea that La Cava might favor pro-life over pro-choice interests.

98 See Watson, 794 N.E.2d at 4-5; Chan, supra note 47, at 126.

99 Shanley, 774 N.E.2d 735.

$100 \quad$ Id. at 737.

101 N.Y. Advisory Comm. on Judicial Ethics Op. 07-136 (2007), available at http://www.nycourts.gov/ip/judicialethics/opinions/07-136.htm.

102 It is possible that it is not permissible to make a not very well-developed statement if it is not an ordinary sentiment that is commonly heard. The Ethics Committee frowned upon a judicial candidate's opposition to plea-bargaining, which is less of a commonplace sentiment than being a "law and order candidate" but was not a very well-developed sentiment. See N.Y. Advisory Comm. on Judicial Ethics Op. 04-95 (2004), available at http://www.courts.state.ny.us/ip/judicialethics/opinions/04-95_.htm.

103 See Chan, supra note 47, at 126.

104 But see Birnbaum, supra note 63, at 74 (pre-Shanley case reaching the opposite result where voters were told they had a clear choice in the election between a tenant and a landlord).

105 Watson, 794 N.E.2d at 5. 
say it. But if you make sure voters understand your position by driving it home repeatedly, you can't. In other words, you can make what in effect are promises, but only in a muffled manner such that voters pay them no mind because it is "everyday" speech. ${ }^{106}$ It would be better to decide, in principle, what sentiments candidates can express, not how loud or forcefully candidates should be able to say those things.

It is likely impermissible for a judicial candidate to respond to questionnaires from political organizations. A 1999 Ethics Commission opinion indicates that judicial candidates may not respond to questionnaires if the questions pertain to issues that may come before the judge, as it would amount to a pledge, promise, commitment, or appearance of commitment. ${ }^{107}$ This issue has been especially contentious in other states where some courts have determined that a survey of views is more like an announcement than a promise as the context indicates that a judge is not being asked to make specific commitments but only to set out an assortment of views. ${ }^{108}$

Ultimately the key distinction in New York is that a statement is unlawful when it favors a single class of litigants. ${ }^{109}$ Under this rubric, William Watson and Walter Hafner violated the rule by favoring law enforcement over criminal defendants. ${ }^{110}$ Margaret Chan and Arthur Birnbaum violated the rule by favoring tenants over landlords. ${ }^{111}$ Patrick McGrath violated this rule by favoring the interests of gunowners over the interests of non gun-owners. ${ }^{112}$

However, it is hard to imagine any contested legal or political issue voters would care about in selecting a judge that does not involve favoring some classes of litigants over others in some way. Voters who care about crime will want a judge whose approach to crime would logically, in one way or another, disfavor criminals or criminal defendants if followed through. Voters who care about tenants will in some way want an advantage for tenants over landlords; presumably this is why they would take the time to select a judge who shares their interests. An announcement of views on a disputed

\footnotetext{
106 Shanley, 774 N.E.2d at 737.

107 N.Y. Advisory Comm. on Judicial Ethics Op. 99-33 (1999), available at http://www.nycourts.gov/ip/judicialethics/opinions/99-33_.htm.

108 Duwe, 490 F. Supp. 2d at 976; Pa. Family Inst., Inc., 521 F. Supp. $2 d$ at 387.

109 Watson, 794 N.E.2d at 7.

110 Id. at 4; Hafner, Jr., supra note 63, at 113-14.

111 Chan, supra note 47, at 126; Birnbaum, supra note 63, at 74.

112 McGrath, supra note 58, at 123.
} 
issue lacks substantive meaning for voters if it cannot be coupled with some plan to act in a certain way while on the bench.

Justice Ginsburg, dissenting in White, argued for the retention of the announce clause in order to preserve the promise clauses; without the announce clause, all promises could be disguised as nonbinding announcements. ${ }^{113}$ But the inverse is also true. If a prohibition on announcements is unconstitutional, it is difficult to preserve a prohibition on promises, since many announcements can be construed as binding promises. This overlap is compounded by the inherent difficulty in distinguishing an announcement from a promise at all. A candidate's pro-life stance, for instance, runs the risk of being interpreted as either. ${ }^{114}$

In addition, keeping one prohibition and not the other may create a chilling effect in which judicial candidates are intimidated from making constitutionally permissible announcements. ${ }^{115}$ Advice given to New York judicial candidates indicates that judges should not air their views on disputed issues, regardless of what the rules say. ${ }^{116}$ For these reasons, the promises clauses may not meet strict scrutiny and may violate the First Amendment rights of judicial candidates.

There is a strong tension between the need for an impartial judiciary and judicial elections in which candidates may be heard and voters may choose freely. ${ }^{117}$ In White, the Supreme Court identified unlawful restrictions on speech in judicial elections. ${ }^{118}$ Many states have since had difficulty determining the correct balance in policing judicial candidate speech. ${ }^{119}$ New York has taken an aggressive approach, applying the pledges, promises, and commitments clauses to limit judicial speech. ${ }^{120}$ This approach may be unconstitutional be-

113 White, 536 U.S. at 819-20 (Ginsburg, J., dissenting). See also Friedland, supra note 82 , at 603 (noting Ginsburg's discussion of promises and announcements indicates that the differences between the two are differences of degree, not of kind).

114 Compare White, 536 U.S. at 771 (announcement at issue involved the criticism of a court decision as a "pro-abortion stance"), with La Cava, supra note 63, at 124 (pledge, promise, or commitment at issue involved a candidate statement that abortion is murder).

115 See Stern, supra note 7, at 118 (stating that judicial candidates cannot anticipate disciplinary rulings because "determinations of implied promises are hardly self-evident," creating a chilling effect).

116 See The High Road, supra note 74.

117 See White, 536 U.S. at 787.

$118 I d$. at 788.

119 See Friedland, supra note 82, at 607-08.

120 Watson, 794 N.E.2d at 4. 
cause of the extent to which these clauses overlap with the announce clause, the degree to which the two kinds of speech cannot be separated from one another, and the limited state interest in the wider context of the problems facing judicial elections. ${ }^{121}$ It is likely that the issue of judicial candidate speech will be before the Supreme Court again in the near future.

121 See Friedland, supra note 82, at 607-08. 